\title{
Factors associated with acute medication overuse in chronic migraine patients
}

\author{
Fatores associados ao uso excessivo de medicação sintomática \\ em pacientes com enxaqueca crônica
}

\author{
Vera Zukerman Guendler ${ }^{1}$, Juliane Prieto Peres Mercante ${ }^{2}$, Reinaldo Teixeira Ribeiro ${ }^{1}$, \\ Eliova Zukerman ${ }^{1}$, Mario Fernando Prieto Peres ${ }^{3}$
}

\begin{abstract}
Objective: To evaluate the prevalence of psychiatric disorders in patients diagnosed with chronic migraine with and without acute medication overuse. Methods: Seventy-two volunteers were recruited from a Family Health Program of the Paraisópolis community in São Paulo (SP), Brazil. These patients were submitted to a detailed headache questionnaire. All participants were submitted to physical and neurological examinations. The following variables were analyzed: age, gender, education level, body mass index, type of overused medication, headache characteristics, and caffeine consumption, lifetime anxiety and mood disorders. Results: Out of 72 patients, $50(69 \%)$ had chronic migraine with medication overuse, and $22(31 \%)$ had chronic migraine without medication overuse. Factors such as age, gender, education level, body mass index, type of overused medication, headache characteristics, and caffeine consumption were not significantly different between the two studied groups. Lifetime anxiety and mood disorders were more common in patients with acute medication overuse $(p=0.003$ and $p=0.045$, respectively). Conclusion: This study has shown a significant association among chronic migraine and medication overuse with lifetime mood and anxiety disorders in patients of the studied population. No association was found for other researched psychiatric disorders.
\end{abstract}

Keywords: Migraine disorders/drug therapy; Chronic disease; Mental disorders; Prevalence; Comorbidity

\section{RESUMO}

Objetivo: Avaliar a prevalência de transtornos psiquiátricos em pacientes com diagnóstico de enxaqueca crônica com e sem uso excessivo de medicação sintomática. Métodos: Setenta e dois voluntários foram recrutados a partir de um Programa de Saúde da Família da comunidade de Paraisópolis, na cidade de São Paulo (SP). Esses pacientes foram submetidos a exames clínico e neurológico. As seguintes variáveis foram analisadas: idade, gênero, nível educacional, índice de massa corporal, tipo de uso excessivo de medicação, características da cefaleia, consumo de cafeína, presença de ansiedade e distúrbios de humor. Resultados: Dos 72 pacientes, 50 (69\%) tinham cefaleia crônica, com uso exagerado de medicação, e 22 (31\%) tinham cefaleia crônica, sem uso excessivo de medicação. Os fatores idade, gênero, nível educacional, índice de massa corporal, tipo de uso excessivo de medicação, características da cefaleia e consumo de cafeína não mostraram diferença significante entre os grupos estudados. Os diagnósticos de ansiedade e de distúrbios de humor ao longo da vida foram mais comuns nos pacientes com uso excessivo de medicação $(p=0,003$ e $p=0,045$, respectivamente). Conclusão: Este estudo mostrou uma associação significativa entre cefaleia crônica e uso excessivo de medicação nos pacientes avaliados, quanto ao diagnóstico de transtornos de ansiedade e de humor ao longo da vida. Não foi encontrada nenhuma associação com outros distúrbios psiquiátricos pesquisados.

Descritores: Transtornos de enxaqueca/quimioterapia; Doença crônica; Transtornos mentais; Prevalência; Comorbidades

\section{INTRODUCTION}

Migraine is considered a chronic, disabling disease which significantly reduces quality of life, and has a considerable economical impact ${ }^{(1,2)}$. Medication overuse headache $(\mathrm{MOH})$ according to the diagnostic

\footnotetext{
Study carried out at Hospital Israelita Albert Einstein - HIAE, São Paulo (SP), Brazil.

${ }^{1}$ Hospital Israelita Albert Einstein - HIAE, São Paulo (SP), Brazil; Universidade Federal de São Paulo - UNIFESP - São Paulo (SP), Brazil.

${ }^{2}$ Hospital Israelita Albert Einstein - HIAE, São Paulo (SP), Brazil; Universidade de São Paulo - USP, São Paulo (SP), Brazil.

${ }^{3}$ Hospital Israelita Albert Einstein - HIAE, São Paulo (SP), Brazil; Universidade Federal de São Paulo - UNIFESP, São Paulo (SP), Brazil; Faculdade de Medicina do ABC - FMABC, Santo André (SP), Brazil.

Corresponding author: Vera Zukerman Guendler - Rua Itacolomy, 601, conj. 62 - Consolação - Zip code: 01239-020 - São Paulo (SP), Brazil - Phone: (55 11) $3255-4122$ -

E-mail: veraguendler@gmail.com/veraguendler@hotmail.com

Received on: Jun 15, 2011 - Accepted on: Aug 31, 2012

Conflicts of interest: none.
} 
criteria of the International Headache Society (IHS) review and its attachment (IHS-2004/2006) ${ }^{(3,4)}$ for chronic migraine $(\mathrm{CM})$ with and without medication overuse is an important factor in the transformation of episodic migraine into $\mathrm{CM}^{(5)}$. In the case of ergotamine, triptans, opioids and combination medications in particular, intake on $>10$ days/month for $>3$ months is required, whereas simple analgesics are considered overused when they are taken on $>15$ days/month for $>3$ months.

Epidemiological studies suggest that up to $4 \%$ of the population may overuse analgesics and other symptomatic medications for management of pain disorders like migraine ${ }^{(6)}$. $\mathrm{MOH}$ occurs in about $1 \%$ of the adult population and in $0.5 \%$ of adolescents ${ }^{(6)}$ from Europe, North America, and Asia ${ }^{(7,8)}$.

$\mathrm{MOH}$ can be distinguished as simple (Type I) or complex (Type II). Simple cases involve relatively short-term drug overuse, relatively modest amounts of overused medications, minimal psychiatric contribution, and no history of relapse after drug withdrawal. In contrast, complex cases may involve long-term use of daily opioids or combined analgesics, multiple psychiatric comorbidities, and/or a history of relapse. Daily use of opioids for other medical conditions, and psychiatric comorbidity including borderline personality disorder, prior history of other substance dependence or abuse, and family history of substance related disorders are risk factors for $\mathrm{MOH}$. Although limited, current research suggests that comorbidity psychiatric disorders are more prevalent in $\mathrm{MOH}$ than in control headache conditions, and may precede the onset of MOH. Such cases appear to have an elevated risk of family history of the use of substance related disorders in $\mathrm{MOH}$ patients, and an increased risk of $\mathrm{MOH}$ in patients diagnosed with personality disorders ${ }^{(9,10)}$.

Mathew ${ }^{(11)}$ was one of the first to point out the connection between transformed migraine and anxiety, depression and insomnia, having identified mood and anxiety disorders in $70 \%$ to $80 \%$ of patient. According to another research $58,7 \%$ of the $\mathrm{CM}$ patient had moderate or severe depression ${ }^{(12)}$.

Even though psychiatric comorbidity in $\mathrm{CM}$ and the influence of acute medication overuse in this disease are well known, little has been enlightened on the connection between these two aspects ${ }^{(13)}$. In case of patients that are refractory to the treatment, such connection requires further research.

\section{OBJECTIVE}

To investigate psychiatric disorders among CM patients with and without influence of acute medication overuse.

\section{METHODS}

We analyzed data from 86 volunteers recruited from a Family Health Program (PSF) of the Paraisopólis community, in the city of São Paulo (SP), Brazil.

At the first moment, patients were submitted to a detailed headache questionnaire, and to physical and neurological examinations. In doubtful cases of secondary headaches, appropriate investigation was performed by the same trained clinician and confirmed by the neurology team. Out of this total, 14 patients were excluded: 6 had secondary headache due to idiopathic intracranial hypertension, 1 had hypophyseal macroadenoma, 1 had right ophthalmic artery aneurysm; 1 had secondary headache attributed to rhinosinusitis, or to moderate or severe head injury, and 5 due to alcohol abuse.

The patients assessed were in the 18 to 65 age group (36.4 \pm 9.5 versus $40.2 \pm 11.3$ years old), being 61 women and 11 men divided into two groups. Group $1 \mathrm{CM}$ had headache present on $\geq 15$ days per month, without the influence of acute medication overuse, whereas Group $2 \mathrm{CM}$ had headache for $\geq 15$ days per month with the influence of acute medication overuse.

The diagnosis for headache was established according to the diagnostic criteria of the IHS review and its attachment (IHS-2004/2006) $)^{(3,4)}$ for CM with and without medication overuse. By then, the patients had had headaches with those features for at least 6 months.

The categories of overused symptomatic medications varied from simple analgesics to narcotics, triptans and combinations of ergot derivatives and caffeine, analgesics and caffeine (Table 1).

All patients were interviewed by a psychologist and a psychic profile was assessed by the SCID $1 / \mathbf{P}^{(14)}$, a structured interview for psychiatric disorders based on the DSM-IV diagnostic criteria ${ }^{(15)}$ and International Statistical Classification of Diseases and Related Health Problems (10th Revision Version for 2007).

The Migraine Disability Assessment (MIDAS) score ${ }^{(16)}$ was used. Anxiety symptoms severity was assessed according to the Hamilton Anxiety Scale (HAM-A) (17) and the Spielberg-State-Trait Anxiety Inventory ${ }^{(18)}$. Depression symptoms were assessed according to the Beck's Depression Inventory (BDI-II) $)^{(19)}$ and the Hamilton Depression Scale (HAM-D) ${ }^{(20)}$.

The research protocol was reviewed and approved by the local Research Ethics Committee. All patients signed the informed consent form.

The $\mathrm{X}^{2}$ test (without the Yates correction), or the Fisher's Exact Test (in case the contingency table 
presented an expected value $<5$ ), was used for data comparison. Differences among continuous data averages were tested by parametric and non-parametric tests, which showed, without exception, similar results. Only the parametric test results will be displayed. The Student's $t$ test was used for independent samples and the Mann-Whitney's test for their non-parametric equivalent.

Statistical significance was considered when $\mathrm{p}<0.05$. All tests were two tailed. Ninety-five percent of Confidence Interval (CI) was calculated in relation to the differences among averages. The whole analysis was calculated according to the Statistical Package for the Social Science (SPSS) 11.5.1 for Windows.

\section{RESULTS}

Seventy-two patients with $\mathrm{CM}$ were included. Twentytwo $(31 \%)$ had $\mathrm{CM}$ without $\mathrm{MOH}$ and $50(69 \%)$ had $\mathrm{CM}$ with $\mathrm{MOH}$.

The socio-demographic data and clinical characteristic, such as age $[36.4 \pm 9.5$ versus $40.2 \pm 11.3$ years; $95 \% \mathrm{CI}=$ $-9.2-1.8 ; t(70)=-1.3 ; \mathrm{p}=0.183]$; gender $(31 \%$ male versus $69 \%$ female; Fisher's exact test; $p=1.000)$; education level $(1.3 \pm 0.7$ versus $1.4 \pm 0.7$ years; $95 \% \mathrm{CI}=-0.4-0.3$; $t(59)=-0.3 ; \mathrm{p}=0.734)$; body mass index $[24.7 \pm 4.3$ versus
Patients with and without $\mathrm{MOH}$ had similar characteristics of pain: time of daily pain in years $[17.3 \pm 10.6$ versus $19.6 \pm 12.4 ; 95 \% \mathrm{CI}=-8.4-3.7 ; t(70)=$ $-0.8 ; \mathrm{p}=0.443$ ]; the duration of the crisis in hours $[20.6 \pm 14.2$ versus $17.7 \pm 10.7 ; 95 \% \mathrm{CI}=-3.5-9.2 ; t(66)=$ $0.9 ; p=0.373$ ] did not differ for pain relief.

The type of overuse medication used for pain relief was not significant enough to differentiate the patients with $\mathrm{MOH}$ from those without $\mathrm{MOH}$ (Table 1).

In this study, $50 \%$ of patients with $\mathrm{CM}$ and $\mathrm{MOH}$ fulfilled the criteria for current major depressive episode (MDE); 59\% for past MDE, specific phobia and lifetime mood disorder; $39 \%$ for major depressive disorder (MDD); $27 \%$ for social phobia, 9\% for panic and obsessive-compulsive disorder; $68 \%$ for generalized anxiety disorder; and $23 \%$ for posttraumatic stress disorder. Of the three significantly more frequent diagnoses in this study, two belonged to the group of anxiety disorders (generalized anxiety disorder $=68 \%$, specific phobia $=59 \%$ ); the third, major depression (59\%) is often followed by important anxious symptoms, fear and avoidance behavior.

In $\mathrm{MOH}$ patients, the diagnosed lifetime anxiety and mood disorders were statistically significant ( $\mathrm{p}=0.003$ and $\mathrm{p}=0.045$, respectively) (Table 2$)$.

Table 1. Comparison of the frequency distribution of medications in patients with and without medication overuse headache

\begin{tabular}{lcccc}
\hline Drugs & With $\mathbf{M O H}(\%)$ & Without $\mathbf{M O H}(\%)$ & $\chi^{2}$ & p-value \\
\hline Dipyrone & 82 & 88 & - & 0.482 \\
Orphenadrine & 9 & 14 & - & 0.712 \\
Isometepten & 23 & 34 & 0.91 & 0.339 \\
Promethazine/adiphenine & 14 & 14 & - & 1.000 \\
Acetylsalicylic acid & 27 & 28 & 0.00 & 0.949 \\
Paracetamol & 27 & 24 & 0.40 & 0.768 \\
Caffeine & 50 & 58 & - & 0.529 \\
NSAIDs & 4 & 12 & - & 0.427 \\
Others & 4 & 8 & - & 1.000 \\
\hline
\end{tabular}

$\chi^{2}$ test or Fisher's exact test.

MOH: medication overuse headache; NSAID:non-steroidal anti-inflammatory drug.

$\left.25.5 \pm 4.7 \mathrm{~kg} / \mathrm{m}^{2} ; 95 \% \mathrm{CI}=-3.0-1.6 ; t(70)=-0.6 ; \mathrm{p}=0.537\right]$ were not significant enough to differentiate the patients with $\mathrm{MOH}$ from those without $\mathrm{MOH}$.
In none of the psychiatric scales used were the scores significantly different, in statistical terms, between the two groups of patients (Table 3 ). 
Table 2. Comparison of the frequency distribution of the qualitative psychiatric diagnosis of patients with and without medication overuse headache

\begin{tabular}{|c|c|c|c|c|}
\hline Characteristics & $\begin{array}{c}\text { Without MOH (\%) } \\
n=22(31 \%)\end{array}$ & $\begin{array}{c}\text { With MOH (\%) } \\
n=50(69 \%)\end{array}$ & $\chi^{2}$ & p-value \\
\hline Current MDE & 53 & 50 & 0.04 & 0.848 \\
\hline Past MDE & 42 & 59 & 1.54 & 0.214 \\
\hline MDE & 37 & 39 & 0.02 & 0.893 \\
\hline Specific phobia & 42 & 59 & 1.54 & 0.214 \\
\hline Social phobia & 16 & 27 & - & 0.520 \\
\hline Panic & 21 & 9 & - & 0.229 \\
\hline Generalized anxiety disorder & 63 & 68 & 0.15 & 0.698 \\
\hline PTSD & 16 & 23 & - & 0.738 \\
\hline OCD & 5 & 9 & - & 1.000 \\
\hline Current anxiety disorder & 63 & 82 & - & 0.196 \\
\hline Lifetime anxiety disorder & 47 & 84 & 9.08 & $0.003^{*}$ \\
\hline Current mood disorder & 37 & 52 & 1.27 & 0.287 \\
\hline Lifetime mood disorder & 32 & 59 & 4.01 & $0.045^{*}$ \\
\hline Others & 16 & 18 & _ & 1.000 \\
\hline
\end{tabular}

${ }^{*} p$ value $<0.05$.

$\chi^{2}$ test

MOH: medication overuse headache; MDE: major depression episode; PTSD: post-traumatic stress disorder; OCD: obsessive-compulsive disorder.

Table 3. Comparison between the scores in the psychiatric scales got by patients with and without medication overuse headache

\begin{tabular}{|c|c|c|c|c|c|c|}
\hline \multirow[t]{2}{*}{ Questionnaires } & \multicolumn{2}{|c|}{$\begin{array}{c}\mathrm{MOH} \\
\text { mean }( \pm \mathrm{SD})\end{array}$} & \multirow{2}{*}{$\begin{array}{c}95 \% \mathrm{Cl} \\
\text { (diference) }\end{array}$} & \multirow[t]{2}{*}{$t$} & \multirow[t]{2}{*}{ DF } & \multirow[t]{2}{*}{ p-value } \\
\hline & Without & With & & & & \\
\hline MIDAS & $22.1(30.6)$ & 29.3 & 11.4 & -0.8 & 60 & 0.440 \\
\hline HAM-A & $14.1(8.1)$ & 14.3 & 4.3 & -0.1 & 60 & 0.931 \\
\hline HAM-D & $12.4(8.6)$ & $11.9(6.7)$ & $-3.6-4.4$ & 0.2 & 61 & 0.828 \\
\hline $\mathrm{BDI}$ & $12.8(8.1)$ & $15.2(10.1)$ & $-7.7-2.8$ & -0.9 & 60 & 0.362 \\
\hline Spielberg state & $40.8(8.5)$ & $45.4(13.1)$ & $-11.2-1.9$ & -1.4 & 61 & 0.162 \\
\hline Spielberg trait & $46.6(10.7)$ & $49.1(12.8)$ & $-9.2-4.2$ & -0.7 & 61 & 0.458 \\
\hline PCS & $214.7(66.0)$ & $198.1(76.3)$ & $-27.4-60.7$ & 0.8 & 47 & 0.451 \\
\hline MCS & $215.2(93.2)$ & $218.8(82.4)$ & $-55.7-48.5$ & -0.1 & 47 & 0.891 \\
\hline
\end{tabular}

MOH: medication overuse headache; SD: standard deviation; CI95\%: 95\% confidence interval; $t$ : Student's t test for independent samples; MIDAS: migraine disability assessment; HAM-A: Hamilton anxiety scale; HAM-D: Hamilton depression scale; BDI: Beck depression inventory; PCS; physical component summary; MCS: emotional component summary.

\section{DISCUSSION}

The findings of the present study did not show a statistically significant difference between the groups of patients with and without $\mathrm{MOH}$ related to age, gender, education level, body mass index, and quality of life. On the other hand, the literature shows a lifetime prevalence of $16 \%$ in the general population, namely, $8 \%$ among men and $25 \%$ among women ${ }^{(21)}$.

The two groups of patients studied have shown similar pain characteristics, which is consistent with the literature descriptions ${ }^{(22)}$.
The type of medication used to relieve the pain did not appear to be a relevant differential factor between patients who overuse analgesics and those who do not, given that the results in this study did not show relevant statistical differences between the both groups. Granella et al. ${ }^{(23)}$ have shown medication overuse in percentages varying from 24 to $76.1 \%$. Yet Castillo et al. ${ }^{(24)}$ have mentioned a rate of $31.1 \%$ for $\mathrm{CM}$ patients with medication overuse, emphasizing that the figures of this behavioral pattern differ between populations of patients from specialized health centers and random samples. 
Other authors ${ }^{(25-29)}$ have shown that in about $90 \%$ of the CM patients, the types of substances overused differ. The most frequently used medications are the combinations of ordinary analgesics with caffeine and other substances.

Spierings et al. ${ }^{(30)}$ have shown that $22 \%$ of their samples used $300 \mathrm{mg}$ of caffeine per day, but $35 \%$ consumed between 100 and $300 \mathrm{mg}$ of caffeine daily, and $48 \%$ below $1,000 \mathrm{mg}$ of salicylic derivatives or its equivalent per day. These figures are not consistent with our results, which suggest a prevalence of $84 \%$ of analgesics containing caffeine.

The issue of psychiatric comorbidities is very important to establish analgesic overuse in CM. The opposite may also occur, that is, a mental disorder diagnosis could be the primary origin of medication overuse.

A retrospective study about the order of occurrence of disorders showed that, in the $\mathrm{MOH}$ Group, psychiatric disorders occurred significantly more often before the transformation from migraine into $\mathrm{MOH}$ than afterwards. $\mathrm{MOH}$ patients have a greater risk of suffering from anxiety and depression, and these disorders may be a risk factor for the evolution of migraine into $\mathrm{MOH}$. Moreover, $\mathrm{MOH}$ patients have a greater risk of suffering from substance-related disorders than migraineurs sufferers. This could be because $\mathrm{MOH}$ is part of the spectrum of addictive disorders ${ }^{(31)}$.

Anxiety disorders are considered as the most prevalent psychiatric disorders group in adults (around 25\%) from the general population ${ }^{(13)}$. Regier et al. ${ }^{(32)}$ also shown that the anxiety disorders as a whole represent the most prevalent group of mental disorders among the population. A further study, the National Comorbidity Survey, confirmed a lifetime anxiety disorder prevalence of $24 \%{ }^{(13)}$.

The pathophysiology of anxiety is attributed to a deficiency on the dopaminergic and serotoninergic neurotransmission; however, the changes in GABA receptors have lately been considered as relevant in its genesis ${ }^{(33)}$. These mechanisms may also be part of the migraine pathophysiology.

The behavioral and psychological mechanisms involved in $\mathrm{CM}$ as a consequence of medication overuse are complex. The route of administration, individual's genetic component, history of some other type of addiction, stress and traumatic life events, fear of having a headache and losing a job or missing an important social event, as well as the sense of relief provided by the analgesic, have a rewarding effect upon the patient that encourages him/her to continue taking more and more analgesics and, as a consequence, rebound headache due to acute medication overuse appears ${ }^{(33)}$.

The present study has shown a significant association among $\mathrm{MOH}$ and lifetime mood and anxiety disorders.

Corchs et al. ${ }^{(34)}$ and Peres et al. ${ }^{(35)}$ observed that anxiety and mood scores were higher among phobic patients and that the number of phobias had a positive correlation with the degree of anxiety and depression ${ }^{(36)}$. Avoidance and fear of having a headache may also underlie analgesic consumption in $\mathrm{CM}$ patients.

Patients of this study were referred for humor and anxiety assessment by means of scales. These scales, however, only identify the symptoms and not determine an appropriate psychiatric diagnosis, which may even encourage, in this population, a falsenegative psychological aspect.

Psychological factors may play a major role in the natural history of $\mathrm{MOH}$. This is an underexplored area of clinical research that deserves further attention. In CM patients, the diagnosis for lifetime anxiety and mood disorders may help to avoid acute medication overuse.

Our study has limitations and cannot be generalized to other patients. Even though the number of patients analyzed has statistical value, it may not be large enough to detect a subtler difference. This is a transverse analysis; no patient was followed-up to determine the disease progression and chronification. A longitudinal design would be more informative, but its complex nature also makes it difficult to perform or establish confounding variables.

\section{CONCLUSION}

This study has shown a significant association among $\mathrm{MOH}$ patients with lifetime mood and anxiety disorders in the studied population. Other psychiatric disorders did not show association with $\mathrm{MOH}$. These findings may help to avoid acute medication overuse.

\section{REFERENCES}

1. Tulen JH, Stronks DL, Bussmann JB, Pepplinkhuizen L, Passchier J. Towards an objective quantitative assessment of daily functioning in migraine: a feasibility study. Pain. 2000;86(1-2):139-49.

2. Bigal ME, Fernandes LC, Moraes FA, Bordini CA, Speciali JG. [Migraine prevalence and impact in employees of the clinical hospital of the medical school of Ribeirao Preto-USP]. Arq Neuropsiquiatr. 2000;58(2B):431-6. Portuguese.

3. Silberstein SD, Olesen J, Bousser MG, Diener HC, Dodick D, First M, Goadsby PJ, Göbel H, Lainez MJ, Lance JW, Lipton RB, Nappi G, Sakai F, Schoenen J, Steiner TJ; International Headache Society. The International Classification 
of Headache Disorders, 2nd Edition (ICHD-II)--revision of criteria for 8.2 Medication-overuse headache. Cephalalgia. 2005; 25(6):460-5.

4. Headache Classification Committee, Olesen J, Bousser MG, Diener HC, Dodick D, First $M$, et al. New appendix criteria open for a broader concept of chronic migraine. Cephalalgia. 2006;26(6):742-6.

5. Mathew NT, Stubits E, Nigam MP. Transformation of episodic migraine into daily headache: analysis of factors. Headache. 1982;22(2):66-8.

6. Dyb G, Holmen TL, Zwart JA. Analgesic overuse among adolescents with headache: the Head-HUNT-Youth Study. Neurology. 2006;66(2):198-201.

7. Diener HC, Limmroth V. Medication-overuse headache: a worldwide problem. Lancet Neurol. 2004;3(8):475-83.

8. Zwart JA, Dyb G, Hagen K, Svebak S, Holmen J. Analgesic use: a predictor of chronic pain and medication overuse headache: the Head-HUNT Study. Neurology. 2003;61(2):160-4.

9. Saper JR, Lake AE 3rd. Medication overuse headache: type I and type II. Cephalalgia. 2006;26(10):1262.

10. Lake AE 3rd. Medication overuse headache: biobehavioral issues and solutions. Headache. 2006;46 Suppl 3:S88-97.

11. Mathew NT. Transformed migraine. Cephalalgia.1993;13 Suppl 12:78-83.

12. Mercante JP, Peres MF, Guendler V, Zukerman E, Bernik MA. Depression in chronic migraine: severity and clinical features. Arq Neuropsiquiatr. 2005; 63(2A):217-20.

13. Kessler RC, McGonagle KA, Zhao S, Nelson CB, Hughes M, Eshleman S, et al. Lifetime and 12-month prevalence of DSM-III-R psychiatric disorders in the United States. Results from the National Comorbidity Survey. Arch Gen Psychiatry. 1994;51(1):8-19.

14. First MB, Spitzer RL, Gibbon M, Williams JB. Structured clinical interview for DSM-IV axis I disorders: patient edition (SCID I/P, version 2.0). New York: Biometrics Research Department, New York State Psychiatric Institute; 1995.

15. American Psychiatric Association. Diagnostic and statistical manual of mental disorders. 4th ed. Washington: American Psychiatric Association; 2000.

16. Stewart WF, Lipton RB, Whyte J, Dowson A, Kolodner K, Liberman JN, et al. An international study to assess reliability of the Migraine Disability Assessment (MIDAS) score. Neurology. 1999;53(5):988-94.

17. Hamilton M. The assessment of anxiety states by rating. Br J Med Psychol. 1959;32(1):50-5.

18. Spielberger CD, Gorsuch RL, Lushene RE. Manual for the State-Trait Anxiety Inventory. Palo Alto (CA): Consulting Psychologists Press; 1970.

19. Beck AT, Ward CH, Mendelson M, Mock J, Erbaugh J. An inventory for measuring depression. Arch Gen Psychiatry. 1961;4(6):561-71

20. Hamilton M. A rating scale for depression. J Neurol Neurosurg Psychiatry. 1960:23(1):56-62
21. Rasmussen BK, Jensen R, Schroll M, Olesen J. Epidemiology of headache in a general population--a prevalence study. J Clin Epidemiol. 1991;44(11): 1147-57.

22. Bigal, ME, Rapoport AM, Sheftell FD, Tepper SJ, Lipton RB. Transformed migraine and medication overuse in a tertiary headache centre--clinical characteristics and treatment outcomes. Cephalalgia. 2004;24(6):483-90.

23. Granella F, Farina S, Malferrari G, Manzoni GC. Drug abuse in chronic headache: a clinic-epidemiologic study. Cephalalgia. 1987;7(1):15-9.

24. Castillo J, Muñoz P, Guitera V, Pascual J. Kaplan Award 1998. Epidemiology of chronic daily headache in the general population. Headache. 1999;39(3):190-6.

25. Isler $\mathrm{H}$. Headache drugs provoking chronic headache: historical aspects and common misunderstandings. In: Diener HC, Wilkinson M. Drug-induced headache. Berlin: Springer-Verlag; 1988. p. 87-94.

26. Schoenen J, Lenarduzzi P, Sianard-Gainko J. Chronic headaches associated with analgesics and/or ergotamine abuse: a clinical survey of 434 consecutive outpatients. In: Rose FC. New advances in headache research. London: Smith- Gordon; 1989. p. 255-9.

27. Mathew NT, Kurman R, Perez F. Drug induced refractory headache--clinical features and management. Headache. 1990;30(10):634-8.

28. Hering R, Steiner TJ. Abrupt outpatient withdrawal of medication in analgesicabusing migraineurs. Lancet. 1991;337(8755):1442-3.

29. Silberstein SD, Lipton RB, Dalessio DJ (editors). Wolff's headache and other head pain. 7th ed. Oxford: University Press; 2001.

30. Spierings EL, Schroevers M, Honkoop PC, Sorbi M. Presentation of chronic daily headache: a clinical study. Headache. 1998;38(3):191-6.

31. Radat F, Creac'h C, Swendsen JD, Lafittau M, Irachabal S, Dousset V, et al. Psychiatric comorbidity in the evolution from migraine to medication overuse headache. Cephalalgia. 2005;25(7):519-22.

32. Regier DA, Myers JK, Kramer M, Robins LN, Blazer DG, Hough RL, et al The NIMH Epidemiologic Catchment Area program. Historical context, major objectives, and study population characteristics. Arch Gen Psychiatry. 1984;41(10):934-41.

33. Jetty PV, Charney DS, Goddard AW. Neurobiology of generalized anxiety disorder. Psychiatr Clin North Am. 2001;24(1):75-97.

34. Corchs F, Mercante JP, Guendler VZ, Vieira DS, Masruha MR, Moreira FR, et al. Phobias, other psychiatric comorbidities and chronic migraine. Arq. Neuropsiquiatr. 2006;64(4):950-3.

35. Peres MF, Mercante JP, Guendler VZ, Corchs F, Bernik MA, Zukerman E, et al. Cephalalgiaphobia: a possible specific phobia of illness. J Headache Pain. 2007; 8(1):56-9.

36. Breslau N, Lipton RB, Stewart WF, Schultz LR, Welch KM. Comorbidity of migraine and depression: investigating potential etiology and prognosis. Neurology. 2003;60(8):1308-12. 